\title{
UPAYA PENINGKATAN KUALITAS PEMBELAJARAN MEMBUBUT MATA PELAJARAN KERJA MESIN LANJUT MENGGUNAKAN MODEL PRAKTIK BERPASANGAN
}

\author{
Roni Suhartono \\ Program Studi Pendidikan Teknologi dan Kejuruan \\ ronie.pas@gmail.com \\ Soeharto \\ Universitas Negeri Yogyakarta
}

\begin{abstract}
Abstrak
Penelitian ini bertujuan untuk: meningkatkan kualitas pembelajaran pada mata pelajaran kerja mesin lanjut menggunakan Model Praktik Berpasangan dan mendapatkan bukti peningkatan hasil belajar kerja mesin lanjut setelah diterapkan Model Praktik Berpasangan. Penelitian ini merupakan Penelitian Tindakan Kelas (PTK), menggunakan desain Kemmis \& Taggart. Pengumpulan data menggunakan teknik observasi, catatan lapangan, wawancara dan studi dokumen. Analisa dilakukan dengan analisa kualitatif untuk menggambarkan suasana pembelajaran yang berlangsung dalam kelas dan analisa kuantitatif untuk melihat perkembangan hasil belajar siswa dan kualitas pembelajaran. Hasil penelitan menyimpulkan bahwa: (1) penerapan pembelajaran menggunakan model praktik berpasangan dapat meningkatkan kualitas pembelajaran ditinjau dari aktivitas guru, aktivitas siswa, dan hasil pembelajaran yang meliputi persiapan kerja, proses kerja, hasil kerja, sikap kerja, dan waktu; dan (2) nilai rata-rata aktivitas guru mengalami peningkatan (dalam siklus $I=77.6$, siklus $I I=87.9$, dan siklus $I I I=96.4$ ). Nilai rata-rata aktivitas siswa mengalami peningkatan (dalam siklus $I=70$, siklus $I I=86$, dan siklus $I I I=96$ ). Nilai rata-rata hasil belajar siswa mengalami peningkatan (dalam siklus I=70, siklus II 72.9, dan siklus III 78.
\end{abstract}

Kata Kunci: Model Praktik Berpasangan, Kualitas Pembelajaran, Praktik Membubut

\section{THE EFFORT TO IMPROVE OF THE QUALITY OF TEACHING LATHE OF ADVANCED MACHINERY WORK USING THE PAIR WORK MODEL}

\begin{abstract}
This study aims to improve the quality of teaching lathe practice of advanced machinery work using the pair work model and obtain evidence of improved learning outcomes in the subject after the implementation of the model. This research is class room action research, used the design by Kemmis \& Taggart. The data were collected through observation, field notes, interviews and document. The data analysis used the qualitative analysis to describe the atmosphere of learning that took place in the classroom and the quantative analysis to see the development of the students'learning outcomes and the quality of learning. The results of the research conclude that: 1) the application of the teaching using the pair work model can improve the quality of teaching in terms of the teachers' activity, and students' activity; and 2) the average activity score of teachers' activity has increased (in Cycle $I=77.6$, in Cycle $I I=87.9$, and in Cycle $I I I=96.4$ ). The average score of students' activity increases (in Cycle $I=70$, in Cycle $I I=86$, and Cycle $I I I=96$ ). The average score of students' learning outcomes has increased (in Cycle $I=70$, in Cycle $I I=72.9$, and in Cycle III=78).
\end{abstract}

Keywords: pair work model, quality of learning, lathe practice 


\section{PENDAHULUAN}

Perkembangan dunia yang semakin mengglobal dipengaruhi oleh kemajuan teknologi, menuntut perkembangan pendidikan juga harus lebih meningkatkan kinerjanya dan membuat inovasi-inovasi agar sekolah tersebut tidak tertinggal dengan kemajuan jaman. Sekolah Menengah Kejuruan (SMK) harus menekankan tingkat kompetenitas siswa terhadap teknologi yang ada saat ini. Hal tersebut, selaras dengan pendapat dari Gagnom (2009: 2697), kompetensi adalah kata kunci di dunia pendidikan saat ini.

Dampak kemajuan dalam pendidikan ditandai dengan meningkat dan berkembangnya kemajuan teknologi disertai dengan sektor-sektor yang lain. Hal ini didukung oleh kompetensi-kompetensi keahlian yang ada di Sekolah Menengah Kejuruan. Kompetensi keahlian yang ada di Indonesia sangat banyak jumlahnya, dan jenis dari kompetensi keahlian tersebut, dapat tergantung dari kondisi wilayah disekitarnya.

Sekolah menengah tingkat lanjut dibagi menjadi dua yaitu SMK dan Sekolah Menengah Atas (SMA), akan tetapi persentase jumlah SMK lebih banyak dibanding SMA. Jumlah SMK tersebut terbagi menjadi kompetensi keahlian yang banyak pula, dan kurang diimbangi dengan fasilitas berupa alat-alat dan perlengkapan yang dibutuhkan. Permasalahan-permasalahan selalu timbul di sekolah,khususnya untuk sekolah swasta, alat-alat praktikum yang tidak sebanding dengan jumlah siswa yang ada di kelas. Pendidikan akan berjalan dengan baik dan lancar serta dapat mencapai tujuan dari pembelajaran apabila fasilitas tersebut dicukupi dengan layak.

Membubut merupakan salah satu kompetensi pada praktik pemesinan. Bubut merupakan suatu mesin yang digunakan untuk mengerjakan pekerjaan-pekerjaan di bidang pemesinan, sebagai contoh membuat suatu poros dengan diameter tertentu dan panjang tertentu. Siswa SMK yang masuk dalam jurusan teknik pemesinan harus dapat menguasai kompetensi keterampilan tersebut, sehingga pada akhirnya, kompetensi yang sudah dimiliki dapat digunakan dalam dunia usaha dan dunia industri.
Pembelajaran praktik membubut dilaksanakan di SMK TKM Teknik Purworejo. Observasi yang dilakukan sebelum melakukan penelitian didapat data pada bengkel pemesinan berupa inventaris mesin dan alat yang ada dibengkel tersebut. Jumlah mesin yang ada, apabila dibandingkan dengan jumlah siswa pada rata-rata tiap kelas yaitu sebanyak 32 siswa, maka jumlah mesin tersebut masih tidak sesuai. Mesin sekerap harusnya sudah tidak ada, atau sudah tidak digunakan dalam praktik pemesinan, karena sudah tidak masuk dalam standar kompetensi dan kompetensi dasar teknik pemesinan.

Praktik pemesinan yang terdapat di SMK TKM Teknik Purworejo terdiri dari dua pekerjaan praktik pada umumnya, yaitu pekerjaan membubut dan pekerjaan mengefrais. Dua pekerjaan tersebut digabung menjadi satu tempat, dan satu waktu, karena masih satu kesatuan dalam pelajaran Kerja Mesin Lanjut. Proses pembelajaran berlangsung, antara pembelajaran membubut dengan mengefrais tanpa ada garis pembatas. Kelemahan yang terjadi adalah, siswa yang ada dibengkel terlihat menjadi tidak beraturan, karena bengkel yang sempit, dan tidak diberi area pembatas antar mesin yang berbeda jenis. Guru harus mengatur pola pembelajaran praktik tersebut, agar siswa dapat belajar dengan aktif.

Perbandingan mesin bubut yang terdapat pada bengkel pemesinan di SMK TKM Teknik Purworejo masih dibilang kurang. Hal tersebut, dapat terlihat selama observasi awal sebelum penelitian, bahwa jumlah mesin yang ada berjumlah 9 (sembilan) dan yang dapat digunakan dengan baik hanya berjumlah 8 (tujuh). Perbandingan yang ideal antara jumlah siswa dengan mesin yaitu satu mesin digunakan untuk satu siswa, akan tetapi hal tersebut sangat sulit untuk diwujudkan, karena membutuhkan dana yang besar untuk mencukupi banyaknya mesin, maka dari itu dengan jumlah yang ada harus dioptimalkan secara baik untuk mencapai kualitas pembelajaran yang sudah direncanakan.

Praktik pemesinan merupakan bentuk kegiatan proses pembelajaran produktif, yang mengajarkan materi kompetensi pemesinan ke- 
pada para siswa dengan cara atau metode yang baku dan benar. Kompetensi pemesinan tersebut meliputi kompetensi membubut, mengefrais, mengebor, menggerinda rata dan silinder, menyekrap, menggergaji, mengasah pahat dan lain sebagainya. Kegiatan ini dapat berlangsung jika didukung oleh beberapa aspek pokok yaitu: aspek fasilitas praktik, bahan praktik, jalannya kegiatan pembelajaran atau Rencana Pelaksanaan Pembelajaran (RPP), job sheet/ operation sheet/instruction sheet, guru, teknisi, siswa dan aspek-aspek pendukung lainya serta metode pembelajaran yang digunakan.

Mesin bubut harus dilengkapi dengan beberapa alat tambahan, untuk memudahkan siswa dalam mengikuti jalannya praktik membubut, alat tersebut diantaranya adalah tempat meletakkan job sheet dan operation sheet, akan tetapi alat atau tempat tersebut belum tersedia. Siswa harus membaca gambar job sheet pada papan depan kelas yang jaraknya dapat menyita waktu praktik, apabila gambar dibawa di mesin dan diletakkan di atas mesin, jelas hal ini akan menimbulkan bahaya, karena konsentrasi siswa akan terganggu. Meletakkan job sheet pada papan depan kelas dapat merugikan beberapa aspek, diantaranya: siswa kehilangan waktu yang banyak untuk berjalan dan membaca gambar, serta siswa tidak dapat melakukan kendali mesin dengan penuh, karena harus berjalan melihat gambar kerja, sehingga akan menambah beban penggunaan listrik disaat mesin ditinggal tidak digunakan.

Metode yang digunakan pada pembelajaran praktik membubut di SMK TKM Teknik Purworejo masih menggunakan metode ceramah dan demonstrasi yang dirasa belum dapat mewakili untuk keberhasilalan dalam proses pembelajaran praktik. Penggunaan metode tersebut masih bersifat teacher centered, sehingga siswa sangat tergantung dengan aktivitas guru yang lakukan. Metode ini harus segera dirubah agar keterampilan siswa dapat terasah dengan baik dan mempunyai sifat kemandirian.

Uraian di atas menimbulkan pertanyaan sejauhmana implementasi metode pembelajaran praktik berpasangan pada pelajaran praktik membubut untuk meningkatkan kualitas pembelajaran siswa. Pertanyaan ini perlu adanya jawaban, oleh karena itu penelitian perlu dilakukan.

\section{PEMBELAJARAN}

Pembelajaran merupakan upaya untuk mengembangkan materi yang akan disampaikan kepada siswa secara terstruktur. Uno (2008: 2), menjelaskan bahwa pembelajaran memiliki hakikat perencanaan atau perancangan sebagai upaya untuk membelajarkan siswa, oleh karena itu siswa dalam belajar, tidak hanya berinteraksi dengan kesuluruhan sumber belajar yang dipakai untuk mencapai tujuan pembelajaran yang diinginkan. Pernyataan tersebut dapat ditarik suatu kesimpulan bahwa pembelajaran merupakan suatu desain yang digunakan untuk membelajarkan siswa dan memusatkan perhatian kepada cara membelajarkan siswa, bukan apa yang sedang dipelajari oleh siswa.

Kata pembelajaran apabila diterjemahkan dari bahasa inggris "instruction" dari dua kategori yaitu belajar (learing) dan mengajar (teaching), setelah itu disatukan dalam satu aktivitas yaitu kegiatan belajar-mengajar yang selanjutnya kini populer disebut dengan pembelajaran (instruction), oleh karena itu untuk memahami hakikat pembelajaran, bila dikaji dari dua istilah di atas menjadi mengajar dan belajar, sehingga pada akhirnya akan memiliki pemahaman yang utuh tentang hakikat pembelajaran.

Belajar tidak pernah lepas dari ruang dan waktu. Semua orang akan selalu belajar walaupun orang tersebut masih kecil, sudah tua, masih sakit ataupun sehat. Penjelasan tersebut diperjelas oleh pernyataan Ian dalam Maclean (2007: 42), seseorang akan belajar selama orang tersebut masih hidup, belajar seumur hidup dapat membantu dalam mempertahankan pekerjaan secara kontinyu, dengan nilai terbesarnya adalah pemenuhan kepentingan pribadi individu.

Konsep belajar pada sekolah kejuruan sedikit berbeda dengan Sekolah Menengah Umum, hal tersebut dapat dilihat pada arah tujuan dari pembelajarannya. Menurut Richard dalam Maclean (2009: 2699), mengutarakan bahwa belajar di Sekolah Menengah Kejuruan (SMK), mengarah pada penguasaan pengetahuan dan perilaku dengan pendekatan kognitif, psikomotorik atau sikap pengembangan pendidikan berbasis kompetensi yang ditujukan untuk pengembangan peserta didik. Kompetensi 
yang dimaksudkan untuk membangun korespodensi sempit antara kebutuhan pasar tenaga kerja dan kapasitas pekerja.

\section{Kualitas Pembelajaran}

Kualitas pembelajaran tergantung dari lingkungan belajar yang efektif. Ifenthaler (2008: 279-280), menjelaskan bahwa lingkungan pembelajaran yang efektif dibedakan menjadi empat jenis, yaitu: 1) lingkungan belajar yang efektif adalah pengetahuan berpusat, 2) lingkungan belajar yang efektif berpusat pada peserta didik, 3) lingkungan belajar efektif adalah penilaian yang berpusat, dan 4) lingkungan belajar yang efektif adalah komunitas berpusat. Pembelajaran efektif ditentukan oleh penggunaan model pembelajaran yang sesuai dengan jenis pembelajaraan yang disampaikan, sehingga menyebabkan peserta didik memperhatikan pengetahuan, keterampilan, dan sikap kerja, selain itu penilaian dalam pembelajaran digunakan untuk mengetahui seberapa jauh siswa dapat menangkap pembelajaran yang sudah diberikan, sedangkan untuk efektifitas dalam komunitas berpusat bertujuan untuk menciptakan rasa nyaman dengan mempertanyakan daripada mengetahui jawaban dan menciptakan ide-ide baru yang dibangun di atas kontribusi individu sebagai anggota.

Kualitas pembelajaran pada teknik, merupakan keberhasilan dalam kualitas kompetensi. Konsep mengenai kompetensi sangatlah luas dan banyak sekali, sehingga konsep kompetensi disesuaikan dengan keadaan dari pekerjaan yang dijalani. Biemans dalam Mulder (2007) membuat penyataan kritis mengenai konsep kompetensi. Pernyataan tersebut adalah: 1) ada banyak definis konseptual kompeten dan kompetensi; 2) ada ketergantungan yang berlebihan pada standarisasi kompetensi; 3) sulit untuk mengitegrasikan pembelajaran di sekolah dengan ditempat kerja, dan konsep kompetensi tidak memecahkan secara otomatis; 4) menentukan kompetensi untuk diakuisisi oleh siswa tidak secara otomatis menghasilkan dengan yang efektif dalam kegiatan belajar; 5) penilaian kompetensi, terutama dalam situasi kerja, adalah latihan padat karya; 6) sejauh mana peran guru dan siswa dalam perubahan ketika pendidikan berbasis kompetensi dilaksanakan; 7) pendidikan kompetensi penting untuk per- hatian struktural pengembangan kompetensi guru dan pengelola sekolah.

Kualitas pembelajaran dapat terlihat dari peningkatan aktivitas siswa dalam pembelajaran. Heidegger dalam Dall'Alba (2009: 11), menerangkan bahwa aktivitas mengeksplorasi karakter yang terletak pada pengetahuan, dan sistem kegiatan berfungsi untuk menyatukan perilaku, alat, tujuan dan sebagainya. Definisi tersebut dapat disimpulkan bahwa, aktivitas pembelajaran tergantung dari seperangkat pembelajaran yang berkaitan langsung, sehingga mendukung peningkatan aktivitas pembelajaran tersebut.

Kualitas pembelajaran akan berjalan searah dengan prestasi belajar, semakin baik kualitas pembelajaran maka prestasi belajar akan semakin baik pula. Prestasi adalah hasil yang telah dicapai seseorang dalam melakukan kegiatan. Menurut Gagne (2005: 49-50), ada lima macam prestasi belajar, yaitu: 1) Keterampilan intelektual atau pengetahuan prosedural; 2) Strategi kognitif; 3) Informasi verbal; 4) Keterampilan motorik; 5) Sikap.

\section{Media Pembelajaran}

Media berasal dari bahasa latin medius yang secara harafiah berarti "tengah" atau "pengantar", sedangkan dalam bahasa arab, media adalah perantara atau pengantar pesan. Menurut Arsyad (2007: 5-7), bahwa media sering dikaitkan dengan atau dipergantikan dengan teknologi, yang berasal dari kata latin tekne ( bahasa inggris art) dan logos ( bahasa indonesia "ilmu"). Erat hubungan antara teknologi dengan media maka kita mengenal kata teknik. Teknik dalam bidang pembelajaran bersifat apa yang sesungguhnya terjadi antara guru dan murid. Kegiatan belajar mengajar kata media pembelajaran sering digantikan dengan istilah-istilah seperti pendengar, bahan pengajaran (instructional material), komunikasi pandang-dengar (audio-visual comunication), pendidikan alat peraga pandang (visual education), teknologi pendidikan (educatioan technology), alat peraga dan media penjelas.

\section{Job Sheet Sebagai Media Pembelajaran Praktik}

Leighbody (1968: 72), menjelaskan bahwa job sheet merupakan daftar tertulis dari 
petunjuk yang memberikan langkah-langkah utama, dalam rangka kinerja untuk menyelesaikan pekerjaan secara keseluruhan. Hal ini dimaksudkan agar orang yang membaca petunjuk tahu bagaimana melakukan setiap langkah, dan memahami semua nama dan istilah teknik yang digunakan. Pemberian lembar kerja kepada siswa akan mampu mengembangkan keterampilan yang dimiliki dengan membaca lembar yang diberikan karena petunjuk-petunjuk sudah ada didalamnya.

Job sheet berisi mengenai gambar kerja yang digunakan sebagai panduan dalam bekerja. Hal tersebut selaras dengan pendapat dari Darmanto (2007: 12), bahwa gambar kerja merupakan suatu alat untuk menentukan produk/ mesin yang akan kita buat, selain itu dapat juga digunakan untuk merencana produk, memberikan informasi tentang cara pengerjaan, batasan dan toleransinya. Gambar kerja dilihat dari fungsinya, sangatlah penting dan wajib ada dalam setiap pembelajaran praktik, khusus pada pekerjaan praktik membubut.

Jenis job sheet menurut Leighbody (1968: 67-68) dalam pembelajaran praktik, dibagi menjadi dua jenis, yaitu a) production job (job produksi), dan b) combining exercise and production (job kombinasi). Pemilihan pada job produksi, maka isi dan pekerjaan yang akan dikerjakan harus dianalisis secara detail, dipilih dan disesuaikan dengan tujuan, serta jumlahnya harus dipertimbangkan secara detail berapa yang harus dikuasai oleh siswa, seberapa jauh kemampuan siswa untuk menyelesaikan job tersebut. Pemilihan memakai job kombinasi maka harus ditentukan juga isi, jenis, dan jumlahnya, berapa jumlah yang pokok (job kompetensi) dan berapa yang job produksi.

\section{Operation Sheet Sebagai Media Pembelajaran}

Operation sheet merupakan media pembelajaran yang termasuk dalam jenis media visual. Leighbody (1968: 72), menjelaskan bahwa operation sheet adalah satu set intruksi yang tertulis secara rinci menggambarkan bagaimana melakukan salah satu langkah yang tercantum dalam langkah kerja/ job sheet. Operation sheet merupakan penjelasan langkah secara detail pada gambar kerja yang tercantum dalam lembar kerja/ job sheet.
Siswa yang mengalami kesulitan dalam membaca gambar kerja pada job sheet, membutuhkan bantuan agar dapat menyelesaikan pekerjaan praktiknya. Operation sheet dapat digunakan untuk menuntun siswa dalam mengerjakan pekerjaan tersebut, karena sudah ada langkah secara terperinci didalamnya. $O p$ eration sheet biasanya tidak terpisahkan dengan job sheet karena operation sheet membuat langkah kerja yang terdapat pada job sheet, sehingga operation sheet tidak dapat berdiri sendiri sehingga membutuhkan pasangan berupajob sheet.

\section{Penggunaan Job Sheet dan Operation Sheet}

Job sheet dan operation sheet merupakan media visual. Pemilihan media menurut Anderson (Sadiman, 2003: 94), bahwa pembelajaran yang membutuhkan pembelajaran kognitif, pembelajaran psikomotorik, pembelajaran sikap dapat menggunakan media visual. Job sheet dan operation sheet merupakan bagian dari insruction sheet atau instruksi kerja yang digunakan untuk pemandu dalam proses pembelajaran praktik. Instruksi kerja dapat membantu dalam keakuratan siswa dalam mengerjakan benda kerja. Rasa kepercayaan siswa akan timbul, karena adanya pemandu saat mengalami kesulitan dalam mengerjakan benda kerja.

Job sheet yang digunakan pada praktik membubut siswa di SMK TKM Teknik Purworejo berupa gambar kerja yang simpel tidak sampai pada langkah pekerjaan yang dikerjakan, sedangkan operation sheet yang digunakan berupa langkah kerja dan penggunaan alat dan mesin serta perhitungan pengerjaan benda kerja. Operation sheet didasarkan atas job sheet sehingga langkah kerja didalamnya seakan-akan sebagai penuntun atau petunjuk untuk menyelesaikan pekejaan pada job sheet. Penggunaan job sheet dan operation sheet akan meningkatkan aktiviitas pembelajaran praktik membubut sesuai dengan teori yang sudah dikemukakan di atas.

\section{Model Pembelajaran Praktik Berpasangan}

Metode praktik berpasangan dapat disebut juga dengan metode practice rehearsal pairs $(P R P)$ yang dikembangkan oleh Silberman. 
Metode praktik berpasangan dalam pembelajarannya membuat kelompok yang didalamnya terbagi menjadi dua anggota yang mempunyai tugas berbeda. Metode praktik berpasangan atau PRP sama-sama digunakan untuk pembelajaran yang bersifat psikomotorik.

Teknik practice-rehearsal pairs menurut Silberman $(2005 ; 237)$, adalah strategi sederhana untuk melatih gladi bersih kecapakan atas prosedur dengan partner belajar. Tujuannya adalah untuk meyakinkan bahwa kedua partner dapat melaksanakan kecakapan dan prosedur. Tujuan metode tersebut tidak berbeda dengan metode praktik berpasangan dan prosedur yang dapat dilakukan saat praktik membubut adalah sebagai berikut:

1. Satu kelas dibagi menjadi beberapa kelompok/pasangan. Setiap pasangan mempunyai dua orang anggota. Setiap anggota mempunyai peran yang berbeda. Siswa pertama menjadi penjelas atau demonstrator dan siswa yang kedua menjadi pengecek.

2. Penjelas atau demonstrator menjelaskan dan atau mendemontrasikan bagaimana melaksanakan kecapakan atau prosedur khusus. Pengecek memverifikasi bahwa penjelasan dan atau demontrator benar, mendorong dan memberikan latihan kalau diperlukan.

3. Partner-partner memutar balik peran. Pengecek menjadi pendemo dan pendemo menjadi pengecek. Penjelas atau demonstrator baru diberi kecakapan atau prosedur lain untuk dilaksanakan.

4. Proses terus berlangsung sampai pembelajaran berakhir.

Pembelajaran praktik berpasangan yang dilakukan dalam satu kelas dibagi menjadi beberapa kelompok-kelompok yang mempunyai fungsi berbeda-beda:

1. Kelompok kerja; Kelompok kerja merupakan kelompok yang terdiri dari satu pasangan, di dalamnya terdapat dua siswa melakukan praktik yang saling bekerja. Fungsi dua siswa atau dua anggota tersebut berbeda, siswa satu sebagai pendemo dan yang satunya sebagai pengecek, setelah itu tugas mereka dapat bergantian untuk bertukar posisi. Kelas XII TP A terdiri dari 32 siswa sehingga pada kelas tersebut mempunyai 16 kelompok kerja.

2. Kelompok mesin; Kelompok mesin merupakan kelompok yang terdiri dari berbagai kelompok kerja, sehingga kelompok mesin ini tidak hanya menampung dari satu kelompok kerja. Penelitian ini dibagi menjadi dua kelompok mesin untuk memudahkan dalam mengatur jalannya pembelajaran dikarena keterbatasan mesin yang ada. Kelas XII TP A terdiri dari 16 kelompok kerja, apabila kelompok mesin yang dibuat sebanyak dua, maka setiap kelompok mesin mempunyai anggota kelompok kerja sebanyak 8. Apabila kelompok mesin yang satu bekerja membubut, maka kelompok lain tidak boleh mengerjakan membubut harus mengerjakan pekerjaan lain. Berikut ini adalah hasil pembagian kelompoknya:

\begin{tabular}{|c|c|c|c|c|c|}
\hline $\begin{array}{c}\text { No } \\
\text { absen }\end{array}$ & $\begin{array}{c}\text { Kel. } \\
\text { kerja }\end{array}$ & $\begin{array}{c}\text { Kel. } \\
\text { Mesin }\end{array}$ & $\begin{array}{c}\text { No } \\
\text { absen }\end{array}$ & $\begin{array}{c}\text { Kel. } \\
\text { kerja }\end{array}$ & $\begin{array}{c}\text { Kel. } \\
\text { mesin }\end{array}$ \\
\hline No 1 & & \multirow{16}{*}{ I } & No 19 & & \multirow{16}{*}{ II } \\
\hline No 5 & 1 & & No 22 & IX & \\
\hline No 2 & & & No 15 & & \\
\hline No 12 & 11 & & No 16 & $X$ & \\
\hline No 3 & \multirow{2}{*}{ III } & & No 24 & \multirow{2}{*}{ XI } & \\
\hline No 14 & & & No 29 & & \\
\hline No 4 & \multirow{2}{*}{ IV } & & No 18 & \multirow{2}{*}{ XII } & \\
\hline No 6 & & & No 27 & & \\
\hline No 5 & \multirow{2}{*}{ V } & & No 25 & \multirow{2}{*}{ XIII } & \\
\hline No 24 & & & No 26 & & \\
\hline No 8 & \multirow{2}{*}{ VI } & & No 20 & \multirow{2}{*}{ XIV } & \\
\hline No 30 & & & No 21 & & \\
\hline No 9 & \multirow{2}{*}{ VII } & & No 31 & \multirow{2}{*}{ XV } & \\
\hline No 11 & & & No 32 & & \\
\hline No 7 & \multirow{2}{*}{ VIII } & & No 23 & \multirow{2}{*}{ XVI } & \\
\hline No 13 & & & No 28 & & \\
\hline
\end{tabular}

\section{METODE PENELITIAN}

Jenis penelitian ini merupakan penelitian tindakan (Action Research). Penelitian ini menggunakan metode yang dikembangkan oleh Kemmis dan Mctaggart (1988: 11-14) menggunakan empat komponen penelitian yaitu perencanaan, tindakan, observasi, dan refleksi.

Penelitian ini dilakukan di SMK TKM Teknik Purworejo terletak di jalan Ahmad Yani 
no.8 Purworejo, tahun pelajaran 2012/2013. Penelitian berlangsung pada tanggal 23 November sampai dengan 11 Februari 2013. Subyek penelitian adalah siswa kelas XII TP (Teknik Pemesinan) A SMK TKM Teknik Purworejo tahun pelajaran 2012/2013 semester I sampai semester II dengan jumlah siswa 32. Penentuan subyek ini diambil, karena Sebagai persiapan untuk Ujian Kompetensi Keahlian (UKK) dan Kelas XII TP A merupakan kelas yang mempunyai prestasi kurang diantara kelas yang lainnya.

Indikator keberhasilan dari penelitian ini adalah adanya peningkatan kualitas pembelajaran praktik membubut, meliputi peningkatan aktivitas siswa, peningkatan aktivitas guru dan hasil kerja siswa setelah proses pembelajaran praktik berlangsung. Aktivitas siswa dan aktivitas guru dinyatakan berhasil apabila hasil nilai dari indikator-indikator tersebut tercapai minimal sebesar $80 \%$ atau masuk dalam kategori sangat baik. Hasil kerja siswa berisi mengenai nilai kompetensi setiap proses untuk kerja berlangsung dan memperoleh nilai minimal sebesar kriteria ketuntasan minimal sebesar 73 .

Jenis tindakan yang dilakukan oleh peneliti dalam melakukan penelitian adalah tindakan kelas yang dilakukan tiga siklus dan setiap siklus terdiri dari:, 1) siklus pertama sebanyak 2 kali pertemuan, 2) siklus kedua sebanyak 2 kali pertemuan, 3) siklus ketiga kali pertemuan. Waktu tindakan setiap pertemuan selama 6 jam pembelajaran pada setiap pertemuan. Teknik pengumpulan data yang digunakan pada setiap pertemuan adalah: observasi, catatan lapangan, tes unjuk kerja, wawancara dan dokumentasi. Pada setiap siklusnya dilakukan analisis data agar data yang diperoleh akurat dan dapat dipertanggung jawabkan menggunakan pendeka$\tan$ kualitatif dan kuantitatif.

\section{HASIL PENELITIAN DAN PEMBAHASAN}

Pada kondisi awal sebelum melakukan penelitian didapatkan data bahwa kelas XII TP A model pembelajaran masih menggunakan sistem teacher centered sehingga siswa terlihat kurang efektif. Kelas XII TP A belum merupakan kelas yang dianggap prestasinya kurang dibandingkan dengan kelas yang lain.Hasil ni- lai dari proses pembelajaran sebelum peneltian tindakan masih dibawah dari nilai kriteria ketuntasan minimal

Berdasarkan hasil penelitian yang telah dilakukan, penelitian dilakukan sebanyak 3 siklus dengan hasil pada siklus 3 sesuai dengan kriteria keberhasilan yang telah ditentukan pada perencanaan penelitian. Berikut ini adalah hasil penelitian dan pembahasan dari penelitian yang telah dilakukan.

\section{Siklus I}

Pembelajaran pada siklus I terdiri oleh dua macam pembelajaran yaitu pembelajaran teori yang berisi mengenai shoptalk untuk persiapan praktik dan pembelajaran praktik yang berisi inti dari pembelajaran. Shoptalk dilakukan terlebih dahulu, setelah persiapan praktik dilakukan dengan baik setelah itu menuju ke pembelajaran praktik.

Tindakan yang dilakukan pada siklus pertama adalah kelas dibagi menjadi 2 kelompok mesin, setelah itu pada kelompok mesin dibagi lagi menjadi kelompok kerja, anggota pada kelompok kerja sebanyak 2 anggota. Setiap anggota pada kelompok kerja mempunyai tugas berbeda, satu anggota menjadi demonstrator dan yang satunya menjadi pengecek pekerjaan demonstrator. Ke dua tugas tersebut bertukar pekerjaan sesuai dengan petunjuk guru, begitupun pertukaran tempat praktik antara kelompok mesin.

Pekerjaan yang dilakukan pada siklus I yaitu membubut landasan pada benteng/pion. Selain pembagian kelompok siswa juga dibagikan job sheet sebagai panduan saat praktik membubut. Hasil yang diperoleh dalam siklus I pada indikator aktivitas guru sebesar $77,6 \%$, aktivitas siswa sebesar $70 \%$ dan hasil pekerjaan siswa sebesar 70. Kriteria yang dihasilkan pada setiap indikator masih dikatakan cukup baik, sehingga perlu dilanjukan kesiklus II.

Pada siklus pertama ada beberapa hal penting yang perlu dikaji setelah dilakukannya penelitian, yaitu: (1) siswa terlihat ada ketergantungan dengan satu teman dikelompoknya sehingga siswa kurang percaya diri dan lebih menggantungkan pekerjaan siswa yang lebih pintar untuk mengerjakan praktik atau membutuh bantuan guru secara langsung; (2) Penilaian 
pembelajaran terbagi menjadi lima indikator/ komponen dengan tingkat kerberhasilan berbeda. Keseluruhan rata-rata kelas berada pada nilai 7.0, detail tiap komponen unjuk kerja adalah sebagai berikut: : (a) persiapan kerja mempunyai nilai rata-rata 7.6, masuk dalam kategori nilai kompeten, (b) proses kerja mempunyai nilai rata-rata 6.8 , masuk dalam kategori belum kompeten, (c) hasil kerja mempunyai nilai rata-rata 6.8 masuk dalam kategori belum kompeten, (d) sikap kerja mempunyai nilai rata-rata 7.1, masuk dalam kategori belum kompeten, dan (e) waktu mempunyai nilai rata-rata 7.6 masuk dalam kategori sudah kompeten.

Hasil pembelajaran yang telah dilaksanakan pada siklus I, diadakan pengkajian terhadap keberhasilan dan kegagalan dalam mencapai tujuan dan untuk menentukan tindak lanjut dalam rangka mencapai tujuan akhir, setelah didiskusikan bersama personil yang berhubungan dengan penelitian yaitu peneliti, koloborator dan guru mata pelajaran menetapkan keputusan keberlanjutan. Siklus pertama terlihat belum memuaskan dan berdasarkan refleksi ditemukan ada hal-hal yang dapat dibenahi, sehingga pada penelitian ini diteruskan ke siklus II.

\section{Siklus II}

Hasil refleksi yang telah dilakukan pada siklus I, maka siklus II harus diadakan untuk memperoleh tingkat keberhasilan yang telah ditentukan. Tindakan siklus II ini terdapat perbedaan atau penambahan agar pembelajaran menjadi lebih aktif dan berkembang. Perbedaan dan penambahan siklus II ini adalah selain menggunakan job sheet, siswa juga menggunakan operation sheet/ langkah kerja pengerjakan benda kerja dan pada siklus I penilaian dilakukan oleh siswa, maka pada siklus II ini siswa akan melakukan penilaian secara mandiri, akan tetapi siswa menilai hasil benda kerja dari kelompok lain dan guru memantau dan membantu pada proses penilaian tersebut.

Pekerjaan praktik membubut yang dilakukan pada siklus II adalah membuat kepada benteng/ pion. Tindakan yang dilakukan pada siklus II secara kesuluruhan hampir sama dengan siklus I, akan tetapi beberapa hal tindakan yang ditambahkan/dilakukan yaitu pada penggunaan job sheet ditambahkan dengan operation sheet dan pada akhir pembelajaran siswa melakukan penilaian hasil kerja pada kelompok lain dengan bantuan pengamatan dari guru praktik.

Operation sheet (OS) dibuat oleh siswa sebagai pekerjaan rumah dan dikumpulkan kepada guru selanjutnya dikonfirmasi kebenaran dari $O S$ yang dikerjakan oleh siswa. Siswa dilarang praktik apabila tidak membuat $O S$, dikarenakan siswa yang tidak membuat hanya akan bertanya kepada guru secara terus menerus atau hanya menunggu pekerjaan teman lain, akhirnya waktu yang digunakan untuk menyelesaikan benda kerja menjadi terhambat.

Siswa yang membuat $O S$ dengan baik terlihat lebih siap dalam melakukan proses membubut. Kondisi tersebut terlihat lebih baik dibanding dengan siklus pertama yang telah dilakukan.

Hasil yang diperoleh dalam siklus II pada indikator aktivitas guru sebesar $87.9 \%$, aktivitas siswa sebesar $86 \%$ dan hasil pekerjaan siswa sebesar 72.9. Semua sub komponen penilaian terlihat naik dibanding dengan siklus pertama, akan tetapi masih ada sub komponen yang mempunyai rata-rata dibawah nilai kriteria ketuntasan minimal yaitu pada proses dengan rata-rata nilai 7.2 dan hasil kerja dengan rata-rata nilai 7.1. Ada dua subkomponen yang belum tuntas masih terdapat 5 kelompok kerja yang tidak menyelesaikan tepat waktu.

Siklus kedua terlihat belum mencapai indikator keberhasilan dan berdasarkan refleksi ditemukan ada hal-hal yang dapat dibenahi sehingga pada penelitian ini diteruskan ke siklus III. Pada siklus ke III lebih ditekankan pada penggunaan metode pembelajaran, penilaian, dan teknik kerjasama didalam kelompok kerja.

\section{Siklus III}

Berdasarkan hasil refleksi pada siklus II maka siklus III harus dilaksanakan untuk memperoleh tingkat keberhasilan yang telah ditentukan. Perbedaan siklus III dibanding dengan siklus II ini adalah pada segi keefektifan model pembelajaran praktik dan dari segi penilaian. Siswa yang di indikasi lebih pintar dibanding teman satu kelompok kerja harus memberikan pengarahan kepada temannya, dan untuk 
segi penilaian, siswa melakukan penilaian hasil kerja kelompok lain tanpa ada bantuan dari guru, sehingga siswa harus bertanggung jawab atas penilaian yang dilakukan, selain itu ada penambahan media pada mesin bubut berupa papan job sheet hal ini dimaksudkan agar membubut tidak memakan banyak waktu dan proses pembelajaran menjadi lebih efektif

Pekerjaan yang dilakukan pada siklus III adalah praktik membubut body benteng/ pion. Tindakan yang dilakukan pada siklus III merupakan kelanjutan dari tindakan pada siklus I dan siklus II, sehingga tidak ada perbedaan yang menonjol hanya memberi tekanan-tekanan tertentu dari hasil refleksi yang telah dilakukan pada siklus II. Tindakan yang dilakukan pada siklus III tidak banyak berbeda dengan tindakan yang dilakukan pada siklus II.

Perbedaan yang menjadi tindakan pada siklus III adalah siswa yang pintar melakukan pekerjaan praktik membubut sebanyak $1 / 3$ dari pekerjaan keseluruhan yang dilakukan pada praktik membubut dan pekerjaan membubut lainnya dilakukan oleh anggota kelompok kerja yang dinyatakan kurang terampil dengan bimbingan siswa yang lebih pintar. Di akhir pembelajaran siswa melakukan penilaian hasil pekerjaan kelompok lain akan tetapi tidak dengan bantuan dan pengamatan guru secara langsung.

Hasil yang diperoleh dalam siklus III pada indikator aktivitas guru sebesar 96\%, aktivitas siswa sebesar $96 \%$ dan hasil unjuk kerja siswa sebesar 78, dengan komponen-komponen pembelajaran: (a) persiapan kerja mendapatkan nilai rata-rata 8.2, (b) proses kerja mendapatkan nilai rata-rata 7.6, (c) hasil kerja mendapatkan nilai rata-rata 7.7, (d) sikap kerja mendapatkan nilai rata-rata 8.1, (e) mendapatkan nilai ratarata 8.1, (f) nilai rata-rata total kompetensi 7.8. Nilai yang diperoleh sudah melebihi dari nilai ketuntasan minimal yang telah ditentukan. Subkomponen tiap siswa ada sebagian yang mendapatkan nilai dibawah dari ketuntasan minimal yang telah ditentukan, akan tetapi apabila dijumlah secara keseluruhan nilai sudahh melebihi dari nilai ketuntutasan yang telah ditentukan.

Hasil yang diperoleh pada siklus III maka peneliti beserta koloborator dan guru mapel menyatakan bahwa tindakan yang dilakukan sudah cukup karena pada tindakan terakhir atau siklus tiga dinyatakan sudah sesuai dengan kriteria keberhasilan yang telah ditentukan.

Hasil penelitian secara keseluruhan dapat dilihat pada tabel dibawah ini

\begin{tabular}{lccc}
\hline \multirow{2}{*}{ KATEGORI } & \multicolumn{3}{c}{ SIKLUS } \\
\cline { 2 - 4 } & $\begin{array}{c}\text { Siklus } \\
\text { I }\end{array}$ & $\begin{array}{c}\text { Siklus } \\
\text { II }\end{array}$ & $\begin{array}{c}\text { Siklus } \\
\text { III }\end{array}$ \\
\hline Aktivitas guru & $77.6 \%$ & $87.9 \%$ & $96.4 \%$ \\
Aktivitas siswa & $70 \%$ & $86 \%$ & $96 \%$ \\
Hasil kerja & 7 & 72.9 & 78 \\
\hline
\end{tabular}

Dari tabel tersebut dapat disimpulkan bahwa pembelajaran praktik membubut menggunakan metode praktik berpasangan dapat meningkatkan aktivitas guru, aktivitas siswa, dan hasil kerja.

\section{SIMPULAN DAN SARAN}

\section{Simpulan}

Berdasarkan data yang diperoleh dan pembahasan hasil penelitian penerapan model praktik berpasangan pada pembelajaran praktik membubut di kelas XII TP A SMK TKM Teknik Purworejo dapat disimpulkan sebagai berikut:

1. Berhasil meningkatkan kualitas pembelajaran praktik membubut pada mata pelajaran kerja mesin lanjut di kelas XII TP A SMK TKM Teknik Purworejo pada indikator aktivitas siswa, aktivitas guru dan hasil belajar siswa.

2. Hasil penerapan model praktik berpasangan pembelajaran praktik membubut pada mata pelajaran kerja mesin lanjut di kelas XII TP A SMK TKM Teknik Purworejo adalah sebagai berikut: a). Aktivitas siswa pada siklus I sebesar $70 \%$, siklus II sebesar $86 \%$, dan pada siklus III sebesar 96\%; b). Aktivitas guru pada siklus I sebesar $77.6 \%$, siklus II sebesar $87.9 \%$, dan pada siklus III sebesar 90\%; c) hasil pembelajaran pada indikator persiapan kerja secara berturut dari siklus I sampai dengan siklus III sebesar 7.6, 7.7, dan 8.2, pada indikator proses kerja secara berturut dari siklus I sampai dengan siklus III sebesar 6.8, 7.2, 
dan 7.6, pada indikator hasil kerja secara berturut dari siklus I sampai dengan siklus III sebesar 6.8, 7.1, dan 7.7, pada indikator sikap kerja secara berturut dari siklus I sampai dengan siklus III sebesar 7.1, 7.4, dan 8.1, pada indikator waktu secara berturut dari siklus I sampai dengan siklus III sebesar 7.6, 7.7, dan 8.0.

\section{Saran}

Ada beberapa saran untuk peneliti berikutnya yang dapat digunakan saat menggunakan praktik berpasangan:

1. Penelitian ini masih membutuhkan beberapa masukan dan perbaikan, sehingga bagi peneliti berikutnya hendaknya lebih memperuncing masalah yang akan diteliti, sehingga tidak menyebabkan hasil penelitian menjadi tidak valid.

2. Penggunaan model praktik berpasanga yang akan digunakan sebagai sarana untuk meningkatkan keberhasilan dalam pembelajaran hendaknya dilakukan secara teliti, sehingga hakekat kemandirian dalam kompetensi dapat tercapai pula.

\section{DAFTAR PUSTAKA}

Arsyad, A. (2007). Media pembelajaran. PT Raja Grafindo Persada: Jakarta

Dall'Alba, G. (2009). Learning to be professionals. New York: Springer Dordrecht Heidelberg London

Darmanto, J. (2007). Modul: bekerja dengan mesin bubut. Jakarta: Yudistira.
Gagne, R.M. dkk. (2005). Principles of intructional design. New York: Wadsworth Publishing Co.

Uno, B. H. (2008). Perencanaan pembelajaran. Jakarta: PT Bumi Aksara.

Ifenthaler, D \& Spector, J.M (Ed.). (2008). Understanding models for learning and instruction. Albert-Ludwigs University, Germany. Springer Sciece+Business Media.

Kemmis, S \& McTaggar, R. (1988). The action research planner $\left(3^{r d} e d\right)$. Australia. Deakin University.

Leighbody and Kidd. (1968). Methods of teaching shop and technical subject. New York :Delmar Publishers. Albany

Maclean, R. (Ed.). (2007). Learning and teaching for the twenty-first century. UNESCO-UNEVOC, International Centre for Edukation, Born, Germany

Maclean, R. \& Wilson. D. (eds). (2009). International handbook of education for the changing world of work. Springer Science Busines Media.

Mulder, M., T. Weigel \& K. Collins (2006). The concept of competence concept in the development of vocational education and training in selected EU member states. A critical analysis. Journal of vocational education and training, 59,1, 65-85.

Sillberman, M.L. (2005). 101 ways to make training active. San Francisco: Preiffer. 